\title{
A Brief Review of Nanocellulose Based Hybrid Membranes for $\mathrm{CO}_{2}$ Separation
}

\author{
Zhongde Dai *, Vegar Ottesen ${ }^{\circledR}$, Jing Deng, Ragne M. Lilleby Helberg and Liyuan Deng * \\ Department of Chemical Engineering, Norwegian University of Science and Technology, 7491 Trondheim, \\ Norway; vegar.ottesen@ntnu.no (V.O.); jing.deng@ntnu.no (J.D.); ragne.marie.helberg@ntnu.no (R.M.L.H.) \\ * Correspondence: zhongde.dai@ntnu.no (Z.D.); liyuan.deng@ntnu.no (L.D.)
}

Received: 30 March 2019; Accepted: 29 April 2019; Published: 6 May 2019

check for updates

\begin{abstract}
Due to the high specific surface area, high mechanical strength and broad possibility of surface modification, nanocellulose has obtained much attention as a new class of bio-based nanomaterials with promising potential in a wide variety of applications. Recently, a considerable amount of research has been aimed to the fabrication of nanocellulose based hybrid membranes for water treatment. However, nanocellulose based hybrid gas separation membrane is still a new research area. Herein, we force on recent advancements in the fabrication methods and separation performances of nanocellulose-based hybrid membranes for $\mathrm{CO}_{2}$ separation, the transport mechanisms involved, along with the challenges in the utilization of nanocellulose in membranes. Finally, some perspectives on future R\&D of nanocellulose-based membranes for $\mathrm{CO}_{2}$ separation are proposed.
\end{abstract}

Keywords: cellulose nanofibers; cellulose nanocrystals; membranes; $\mathrm{CO}_{2}$; gas separation

\section{Introduction}

Nanocellulose is a class of nanomaterials (one or more dimensions between 1 and $100 \mathrm{~nm}$ ) composed of the biopolymer cellulose. Like the biopolymer from which these nanomaterials are composed, nanocellulose are highly versatile; they have a very high tensile strength [1], high biodegradability, low toxicity, can be made biocompatible and can readily be modified chemically. The biopolymer has a long history in human endeavors. More recently scientific curiosity and financial interest have increased the exploration of nanostructures composed of cellulose (Figure 1). Casting a wide net in Scopus with the search term nano AND cellulos* we find 6449 results at the time of writing, and 132,109 patents. By the end of 2018 this was 6131 and 130,143 respectively, suggesting a continued rapid climb. The admittedly naive search term suggests a large and growing scientific and industrial interest in nanocellulose. 
(A) Document by year

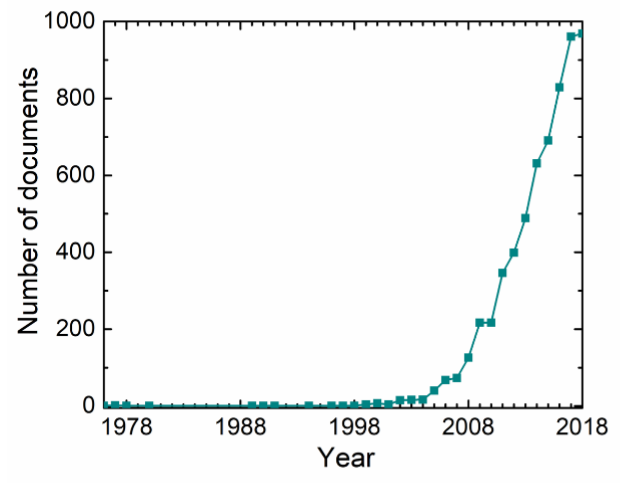

(B) Document by field

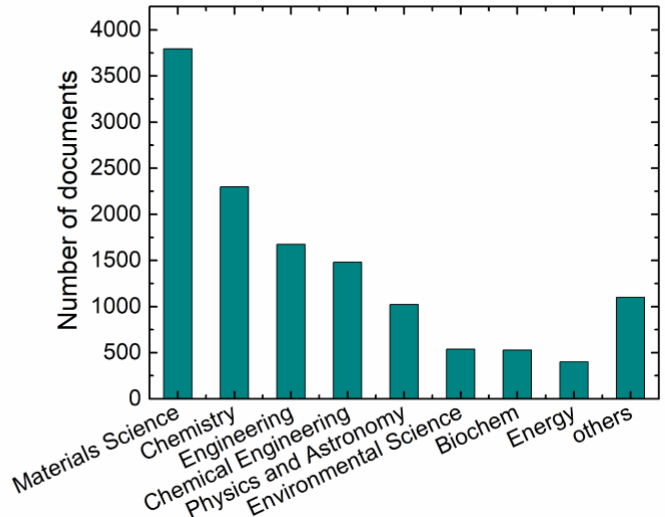

Figure 1. Publications per year as well as publications by field. Data from Scopus search using search term TITLE-ABS-KEY (nano AND cellulos*). Search limited to the range 1976-2018. Search made 24 March 2019 09:00 GMT. Note that one document may be counted as contributing to several fields.

Various kinds of nanocellulose are produced, many of which are available commercially, or produced in a laboratory setting. These are commonly divided into three main groups: Cellulose nanofibrils (CNF), cellulose nanocrystals (CNC) or bacterial nanocellulose (BNC), each with sub-groups with a wide range of properties and applications. In the history of these nanomaterials various names have been and to some extent still are used in literature. In the current paper, we will adhere to nomenclature suggested by TAPPI and ISO, namely CNF, CNC, and BNC, respectively. This versatility has led to applications in a wide range of fields, including but not limited to drug delivery [2], tissue engineering [3], packaging films [4], nanocomposites [5], paper and board [6], rheology modifiers [7] and photonics [8].

\subsection{Chemistry and Structure of Nanocellulose}

Chemically, cellulose is a homopolysaccharide, specifically $\beta(1 \rightarrow 4)$ linked D-glucose units (Figure 2). Given that all substituents of the D-glucose monomer are equatorial, the repeating unit for cellulose is quite planar, or "flat". The rotation around the glycosidic bond ensures the polymer itself is linear. The combination of planar monomers and linear polymers enables the polymer chains to bond to one another into larger structures like fibers. Interactions between polymers are through inter-chain hydrogen bonds (within the plane) and van-der-Waals interactions (out of the plane). This amphiphilic interaction as a basis for the insolubility of cellulose in water is termed the Lindman hypothesis [9-11].

a

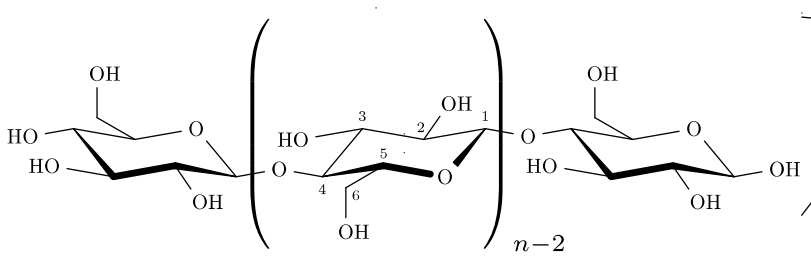

$\mathrm{b}$

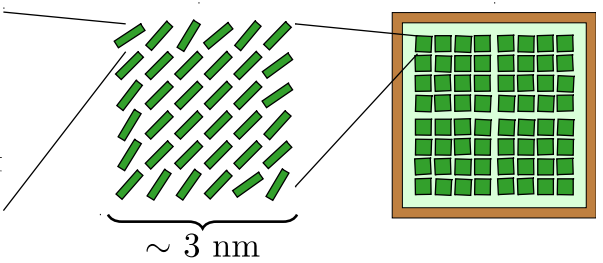

Figure 2. Cellulose molecular structure (a). Cellulose consists of $\beta-(1 \rightarrow 4)$ linked D-glucose units. Literature frequently lists cellobiose as the repeating unit, though this is criticized [12]. Common model for cellulose elementary fibril cross-sectional structure in higher order plants (b). Each rectangle represents one cellulose polymer seen down its axis. Model for cross-section of cellulose microfibril structure in plants proposed by Fengel and Wegener [13] (c). One square represents one elementary fibril. Cellulose is dark green $(\bigcirc)$, hemicellulose is light green $(C)$ lignin is brown $(\odot)$. Figure adapted from Reference [14]. Used with permission. 


\subsection{Fabrication of Different Nanocelluloses}

The most common sources of nanocellulose are plant matter. Nanocellulose, either CNF or CNC from plant matter are prepared by the disintegration of the source material. Various methods, chemical and/or mechanical, can be employed to produce these. This section will only briefly list the commonly used methods for nanocellulose preparation. Further details on nanocellulose production can be seen in a range of review papers and books focusing on this matter [15-18].

\subsection{1. $\mathrm{CNF}$}

CNF, previously "microfibrillated cellulose" (MFC), was first reported in the early 1980s, then produced through high pressure homogenization of softwood pulp [19]. Since the 1980s a wide range of techniques have been applied to produce cellulose nanofibers. The primary means to produce CNF by mechanical means remain high pressure homogenization, though microfluidization and grinding are also common $[16,17,20]$. Other techniques are also applied, though they are less common $[16,17,20]$. Mechanical fibrillation is energy intensive and produces a morphologically heterogenous product (Figure 3a) [21]. Chemical pre-treatments such as TEMPO-mediated oxidation [22,23] can be used to produce fibrils with narrower size distributions, smaller diameters at substantially lower energy requirements (Figure 3b).
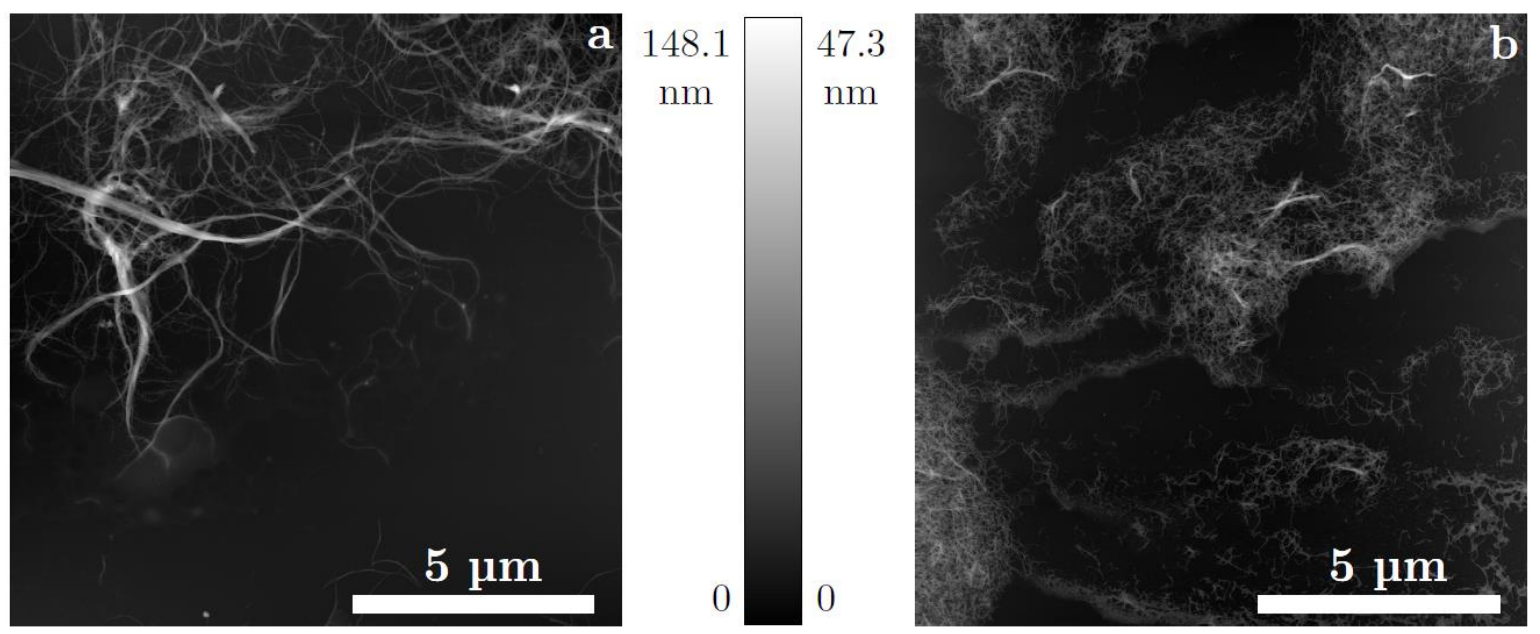

Figure 3. AFM (atomic force microscopy) micrographs of mechanically prepared (a) and TEMPO-oxidized (b) CNF. Micrographs show height information, pixel values range from $0 \mathrm{~nm}$ (black) to $\max$ (white). Max is $148.1 \mathrm{~nm}$ for subfigure $a$ and $47.3 \mathrm{~nm}$ for subfigure $b$. Imaged CNF qualities are described in detail in Reference [24].

\subsection{2. $\mathrm{CNC}$}

CNC is also referred to as nanocrystalline cellulose (NCC), crystallites, cellulose nano-whiskers (CNW), whiskers, or rodlike cellulose microcrystals [15]. CNC can be produced by attacking and removing areas with higher disorder. Classically this is done by acid hydrolysis, though other approaches including enzymatic hydrolysis or TEMPO mediated oxidation [25] can also be used [11].

The morphology of CNCs, primarily their length, depends on the hydrolysis time [26], acid concentration [27] and on the origin of the raw material [11].

\subsubsection{BNC}

Bacterial nanocellulose (BNC, also referred as bacterial cellulose (BC), microbial cellulose and biocellulose) has been known since 1886 [28], when BNC pellicles produced by Gluconobacter xylinus was first identified as cellulose. Since the initial discovery of BNC we have found that several bacterial genera produce cellulose as a part of their metabolic processes [29]. 
Fibrils produced by G. xylinus have a rectangular cross-section, and are frequently described as ribbons rather than fibrils [30]. Nanofibrils produced by different bacteria have different morphologies and properties [29]. BNC also has a higher degree of crystallinity than most plants [31,32], leading to a higher tensile strength for BNC.

\subsection{Nanocellulose Applications}

Since the last decade, nanocellulose has been used in abundant various applications ranging from composite reinforcement, food packaging materials, conductive materials to rheological modifiers. However, many of the proposed applications were not marketed because of the high energy consumption and production costs [33]. Currently, due to the fact that the isolation methods to produce nanocellulose are much less costly, the perspectives on the industrial production of nanocellulose have been changed. It has been applied in a wide range of fields, including but not limited to drug delivery [2], tissue engineering [3], packaging films [4], nanocomposites [5], paper and board [6], rheology modifiers [7] and photonics [8].

Nanocellulose has been widely studied as components of materials for food packaging. It has been found out that the use of nanocellulose can extend the food shelf life and also improve the food quality as they can work as carriers for some active substances, such as antioxidants and antimicrobials [34-39].

Nanocellulose can be easily fabricated into aerogels with high porosity, large surface area and low density; thus it has been proposed as adsorbents for different applications, including removing various pollutants from waste water, such as heavy metals, dissolved organic pollutants, dyes, oil and other undesired effluents [40].

The use of nanocellulose as reinforcement in nanocomposites has also become a popular research topic $[1,41,42]$. The tailorability, design flexibility and processability of nanocellulose-polymer composites permit broad utilization in the various applications, like automotive, electronics, biotechnology industries, etc [43].

Besides these applications mentioned above, nanocellulose also have been used in many novel applications such as rheological modifiers [44], food science [19,45], 3D-printing additives [46], printed electronics [47], sensing and biosensing [48], energy devices [49,50], drug delivery vehicles [2,51], and membrane separation $[52,53]$.

\section{Nanocellulose Hybrid Membranes}

Membranes can be used to separate different mixtures by allowing some species to pass while the others are stopped. Permeability and selectivity are the two key parameters for a membrane. Developing membrane with both high permeability and selectivity is always desired to increase the efficiency of the membrane separation processes.

The combination of unique features of nanocellulose, such as high strength, chemical inertness, hydrophilic surface chemistry, and high specific surface area, makes it a very promising material for high-performance membranes. In this section, the different methods to fabricate nanocellulose based hybrid membranes are briefly introduced, and the separation applications of the membranes are summarized.

\subsection{Nanocellulose Based Membrane Fabrication}

There are various basic methods to fabricate membranes of different morphologies [54,55]. In the case of nanocellulose base membranes, several membrane fabrication methods have also been developed considering the special properties of the nanocellulose fibers and the membrane casting suspension, as illustrated in Figure 4 and summarized as follows: 
A) Vacuum filtration



B) Solvent casting
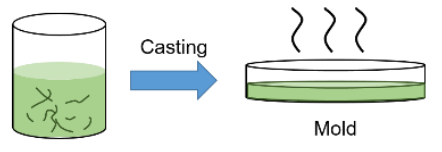

$$
\text { Drying }
$$

Mold

C) Dip coating

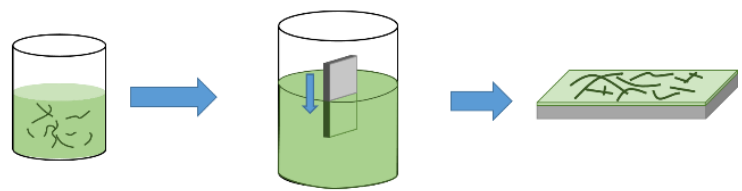

D) Electrospinning

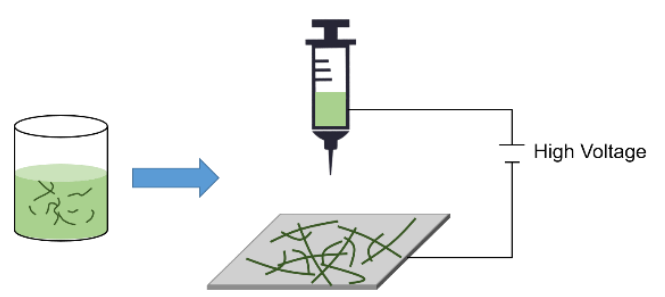

Figure 4. Different methods used for nanocellulose membrane fabrication.

\subsubsection{Vacuum Filtration}

Vacuum filtration is a fast, simple, and accessible process to produce layered structures of nanocellulose membranes and nanopapers followed by optional hot-pressing. The thickness and pore size of resultant membranes could be controlled by the amount and concentration of nanocellulose suspensions [56]. Different porous supports have been used in this method, including cellulose paper [57] and nylon filter membranes [56,58].

\subsubsection{Casting Evaporation and Coating}

Self-standing membranes for gas separation is normally prepared via casting evaporation of dilute nanocellulose suspension in a petri dish [59,60]. Generally, the nanocellulose dispersion needs to be diluted to a rather low concentration (heavily dependent on surface chemistry and fibril diameter, but generally $<1 \mathrm{wt} \%$ ) to reduce possible agglomeration $[61,62]$.

Nanocellulose based thin-film-composite (TFC) membranes can be fabricated by knife casting method [59] or dip-coating method [62]. By controlling and optimizing the operation parameters, TFC membranes with a selective layer thickness of $\sim 500 \mathrm{~nm}$ can be obtained [62].

\subsubsection{Electrospinning}

Membranes prepared from electrospining usually consist of lower basis weight, larger effective surface area, and higher effective porosity with continuously interconnected pores [63]. Incorporating nanocellulose inside the electrospinning membranes could change the membrane surface charge density, enhance the overall effective surface area and improve functional group density [64,65]. Moreover, the $\mathrm{CNC}$ content could affect the mean pore size and pore size distribution of this multilayered nanofibrous system, and thus the separation performance.

\subsection{Nanocellulose Hybrid Membrane Applications}

Cellulose fibers have a long tradition as filter materials dating back to ancient times [66]. In the past decades, nanocellulose has been intensively studied as membrane materials for water purification, 
possibly due to the inherent hydrophilicity of nanocellulose combined with tunable surface chemistry, which could be promising for reducing the bio-fouling or organic fouling [67-69]. Nanocellulose based membranes have been also applied in many water purification processes, such as bacteria removal [70], virus removal [58], and the removal of pollutants (e.g., heavy metal species and dyes) originated from either industrial or natural sources [52], and oil/water separation [56,71,72].

In addition, adding nanocellulose into polymer electrolyte (e.g., Nafion) could not only improve the mechanical and thermal stability, but also reduce water uptake plus area and volume swelling ratios in proton conducting membrane, which is one of the essential and critical materials in both proton exchange membrane fuel cell (PEMFC) and direct methanol fuel cell (DMFC). The cross-linked structure formed by the nanocellulose could also effectively reduce the undesired methanol crossover [73-76].

The nanocellulose based membrane has also been used in other process such as solar cells [77], membrane distillation (MD) [78], organic solvent nanofiltration (OSN) [79] and hemodialysis [80]. A new application of nanocellulose membranes for $\mathrm{CO}_{2}$ separation have been emerged and attracted great attention during the recent five years; Promising separation performances of the membranes have been reported [59,62].

\section{Nanocellulose Hybrid Membranes for Gas Separation}

Membrane separation has been widely accepted as a promising alternative for traditional $\mathrm{CO}_{2}$ separation technologies (e.g., absorption and/or adsorption) due to its high cost efficiency, high modularity, small footprint, lower or no chemical emissions, and ease of operation. However, both high selectivity and high gas permeability is required to make the gas separation membranes economically favorable in industrial applications $[54,81]$.

As previously discussed, CNC and CNF differ in length as well as crystallinity (CNC is pre-dominant crystalline; $\mathrm{CNF}$ is frequently described as amorphous with crystalline regions). The advantages of CNC include uniform size with nanometric dimensions in both length and width. In certain applications such as high pressure gas separations, $\mathrm{CNF}$ with a higher aspect ratio and tensile strength might be desirable [82]. As mentioned in Section 1.2, CNF is often produced in a two-step process starting with a chemical/ enzymatic pre-treatment step followed by a mechanical step. In addition to improve the processability as well as making the size distribution more uniform, the pre-treatment step can contribute to nanocelluloses with different properties tailored different gas separation applications (e.g., introduction of $\mathrm{CO}_{2}$ reactive groups) [82].

Based on the previous studies on nanocellulose, nanocellulose membranes have very low gas permeability, hence they are usually used as gas barrier materials, not for gas permeation applications [83]. In 2010, Minelli et al. investigated the $\mathrm{O}_{2}$ and $\mathrm{H}_{2} \mathrm{O}$ transport properties in CNF (labelled MFC by the authors) films [84], and found out that dry CNF films showed excellent oxygen and $\mathrm{H}_{2} \mathrm{O}$ barrier properties. However, a $4 \sim 5$ orders of magnitude increase in both $\mathrm{O}_{2}$ and $\mathrm{H}_{2} \mathrm{O}$ permeability was observed when the water content inside membranes was increased.

Wang et al. summarized studies of applying nanocellulose for gas barrier application [85]. Similar results were obtained for different nanocellulose: they could work as excellent oxygen barrier materials at the dry state and the performances are still good at low relative humidity $(<65 \%)$, but they are a poor moisture barrier. In addition, the $\mathrm{O}_{2}$ permeability increases 5 orders of magnitude as the relative humidity ( $\mathrm{RH}$ ) value increases from 0 to $60 \%$ (as shown in Figure 5). Further increasing the $\mathrm{RH}$ value may lead to even higher gas permeability. 


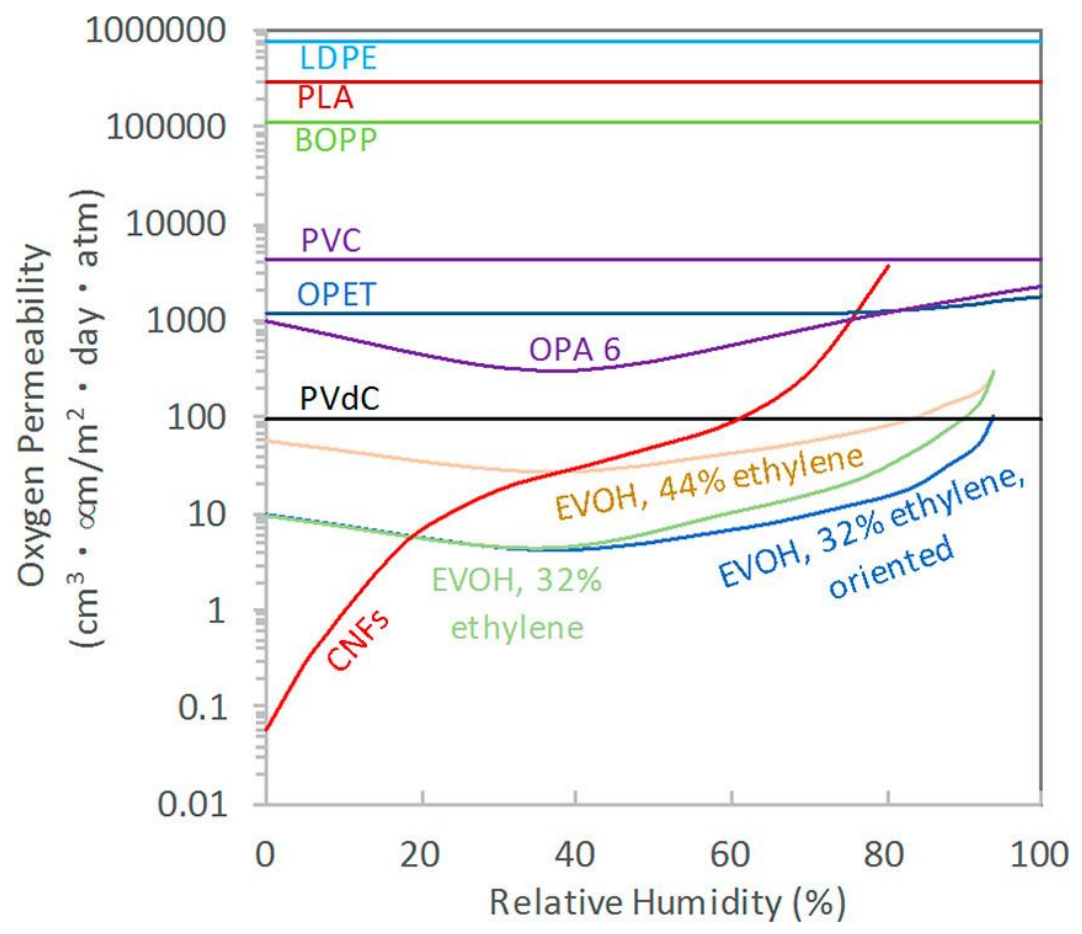

Figure 5. Oxygen permeability changes with relative humidity at $23-25{ }^{\circ} \mathrm{C}$ for films of carboxymethylated CNFs and other polymers, reproduced with permission from Reference [85]. Copyright (2019) American Chemical Society. $\left(1 \frac{\mathrm{cm}^{3} \cdot \mu \mathrm{m}}{\mathrm{m}^{2} \cdot \mathrm{day} \cdot \mathrm{atm}}=1.5229 \times 10^{-6}\right.$ Barrer, 1 Barrer $=$ $\left.10^{-10} \frac{\mathrm{cm}_{\mathrm{STT}}^{3} \cdot \mathrm{cm}}{\mathrm{cm}^{2} \cdot \mathrm{s} \cdot \mathrm{cmHg}}\right)$.

\subsection{Facilitated Transport Membranes}

Inspired by the findings from Minelli et al., which concluded that the nanocellulose membrane characteristics could be changed from barrier to highly permeable by simply controlling the RH value, Ansaloni et al. firstly investigated the possibility of applying $\mathrm{CNF}$ as $\mathrm{CO}_{2}$ separation membrane materials [59]. In their work, $\mathrm{CO}_{2}$ transport properties of membranes fabricated from neat $\mathrm{CNF}$ and $\mathrm{CNF}$ / polyvinylamine (Lupamin $囚$ ) was studied under different $\mathrm{RH}$ values, ranging from $\sim 50$ to $\sim 100$. In the case of pure CNF membranes, similar to the trend of $\mathrm{O}_{2}$ reported before, a dramatic increment was found for all the tested gases (i.e., $\mathrm{CO}_{2}, \mathrm{CH}_{4}$ and $\mathrm{N}_{2}$ ), which shows at least 3 orders of magnitude enhancement as the $\mathrm{RH}$ increases from $50 \%$ to $\sim 100 \%$. Under optimized conditions, a $\mathrm{CO}_{2} / \mathrm{N}_{2}$ selectivity of over 500 can be obtained. However, the maximum $\mathrm{CO}_{2}$ permeability value obtained from the pure CNF membrane is only about 25 Barrer, which is a rather low value compared to many commercially available polymeric membranes (e.g., polyimide, polyethylene glycol-based polymers).

On the other hand, mixing CNF into Lupamine $\AA$ resulted in a clear enhancement of the permeation coefficient for all the three tested gases with respect to neat CNF films in the entire humidity range. However, due to high swelling and dilation of the matrix at high water content, a major increase of methane and nitrogen permeability was obtained, which resulted in a reduction of $\mathrm{CO}_{2} / \mathrm{N}_{2}$ and $\mathrm{CO}_{2} / \mathrm{CH}_{4}$ selectivity at high humidity conditions. The gas permeation results for $\mathrm{CO}_{2} / \mathrm{N}_{2}$ and $\mathrm{CO}_{2} / \mathrm{CH}_{4}$ separation are presented in Figure 6.

In another report from the same group [60], carboxymethylated CNF was employed to mix with Lupamin $囚$, followed by a thermal treatment at $105{ }^{\circ} \mathrm{C}$. Different from the neat $\mathrm{CNF}$, in which the $\mathrm{CO}_{2} / \mathrm{CH}_{4}$ selectivity firstly increases and then decreases at high $\mathrm{RH}$ condition, both $\mathrm{CO}_{2}$ permeability and $\mathrm{CO}_{2} / \mathrm{CH}_{4}$ selectivity increase with $\mathrm{RH}$ in carboxymethylated $\mathrm{CNF}$ membranes. In the case of carboxymethylated $\mathrm{CNF} /$ Lupamin $囚 m e m b r a n e s$, quite comparable results were obtained with respect to the neat CNF/Lupamin $\AA$ membranes [86]. 
(A)
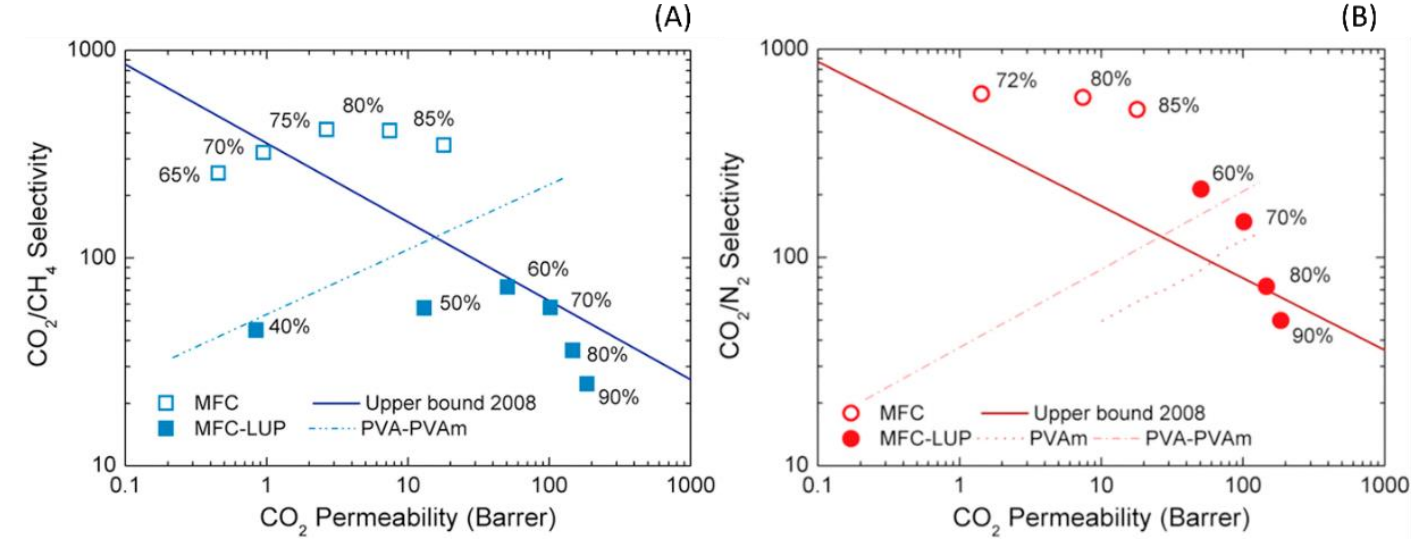

Figure 6. Robeson plots for $\mathrm{CO}_{2} / \mathrm{CH}_{4}(\mathrm{~A})$ and $\mathrm{CO}_{2} / \mathrm{N}_{2}$ (B) separation for the pure $\mathrm{CNF}$ (labelled MFC by the authors) and CNF-Lupamin $\left(\right.$ nnanocomposite membranes (results obtained at $35^{\circ} \mathrm{C}$ and 1 bar). Reproduced with permission from Reference [59].

CNF was also employed in making nanocellulose/Lupamin®hybrid membranes [86]. Self-standing films with different nanocellulose content (from 30 to $70 \mathrm{wt} \%$ ) were fabricated. It has been found out that the membrane permeability consistently increased with water vapor, and a higher content of Lupamin in the film led to an increment of both gas permeability and selectivity. The maximum selectivity (135 for $\mathrm{CO}_{2} / \mathrm{CH}_{4}$ and 218 for $\mathrm{CO}_{2} / \mathrm{N}_{2}$ ) was obtained at $60 \mathrm{RH} \%$, while the maximum $\mathrm{CO}_{2}$ permeability (187 Barrer) was observed at $80 \% \mathrm{RH}$.

Instead of mixing nanocellulose into a polymeric matrix, Zhang et al. developed nanocellulose free standing membranes by dissolving $\alpha$-Cellulose in zinc chloride/calcium chloride solution [87]. $\mathrm{Zn}^{2+}$ ions reduce the pristine hydrogen bonds that normally bind the cellulose chains together, and $\mathrm{Ca}^{2+}$ ions facilitate interactions among the $\mathrm{Zn}^{2+}$-cellulose chains to form nanofibrils. It is claimed that the $\mathrm{Zn}^{2+}$ ion could work as fixed site carriers for $\mathrm{CO}_{2}$ gas molecule. The highest $\mathrm{CO}_{2}$ permeability (155.0 Barrer) was obtained from the membrane with the highest $\mathrm{Zn}^{2+}$ content $(22.2 \%)$, with selectivity of $27.2\left(\mathrm{CO}_{2} / \mathrm{N}_{2}\right)$ and $100.6\left(\mathrm{CO}_{2} / \mathrm{O}_{2}\right)$.

In another study, BNC (labelled bacterial cellulose, BC, by the authors) was used as membranes for $\mathrm{CO}_{2}$ separation purpose [88]. From the FTIR results, it has been found out that there is a strong interaction of $\mathrm{CO}_{2}$ with the $\mathrm{BNC}$ membrane. The BNC membrane was further modified with silk fibroin protein as well as $\mathrm{ZnO}$ nanoparticles to improve the interaction between the $\mathrm{CO}_{2}$ and the membrane. However, all the three membranes show rather low gas permeability, which is $2.73,2.69$ and 2.66 Barrer for the pristine, silk fibroin-modified and $\mathrm{ZnO}$ nanoparticles-modified $\mathrm{BNC}$ membrane, respectively. As the $\mathrm{CO}_{2}$ is the only gas tested, there is no selectivity reported.

\subsection{Nanocellulose/Polymeric Hybrid Membranes Based on Solution-Diffusion Mechanism}

Uribe mixed nanocellulose with two commercially available polymeric membrane materials, which are cellulose acetate (CA) and poly ether imide (PEI) [89]. Even though high variability $(>60 \%)$ was observed on the gas permeation test, it can be clearly observed that adding only $0.1 \mathrm{wt} \%$ of $\mathrm{CNFs}$ into the polymeric matrix leads to a significant improvement on $\mathrm{CO}_{2}$ permeance, for both $\mathrm{CA}$ and PEI membranes. However, the $\mathrm{CO}_{2}$ permeance falls in the low region: the maximum $\mathrm{CO}_{2}$ permeance obtained is about $2 \mathrm{GPU}\left(\mathrm{GPU}=10^{-6} \frac{\mathrm{cm}_{\mathrm{STP}}^{3}}{\mathrm{~cm}^{2} \cdot \mathrm{s} \cdot \mathrm{cmHg}}\right.$ ) for CA/nanocellulose membranes and around $50 \mathrm{GPU}$ for the PEI/nanocellulose membranes. In addition, the addition of CNF improved the permeance of both gases, at the cost of a decrease in $\mathrm{CO}_{2} / \mathrm{N}_{2}$ selectivity (reduced from $\sim 20$ to $5 \sim 10$ ).

Jahan et al. mixed CNC with polyvinyl alcohol (PVA) and fabricated them into thin-film-composite (TFC) membranes for $\mathrm{CO}_{2} / \mathrm{CH}_{4}$ separation application [90]. It is found out that increasing $\mathrm{CNC}$ concentration of CNC in coating solution, the thickness of the selective layer (PVA + CNC) is also increased. So $1.5 \mathrm{wt} \% \mathrm{CNC}$ is the optimized content in the PVA matrix, a higher or lower content 
resulted in reduced $\mathrm{CO}_{2}$ permeance and $\mathrm{CO}_{2} / \mathrm{CH}_{4}$ selectivity. Under optimized conditions, a $\mathrm{CO}_{2}$ permeance of $\sim 100 \mathrm{GPU}$ and a $\mathrm{CO}_{2} / \mathrm{CH}_{4}$ selectivity of 39 can be obtained. The same system has also been employed to separate $\mathrm{CO}_{2} / \mathrm{CH}_{4}$ at high feed pressure conditions [91]. By introducing small amount of CNC (1 2 $\mathrm{wt} \%)$ into the PVA matrix, followed by adjusting the $\mathrm{pH}$ of the resultant solution, a $\mathrm{CO}_{2}$ permeance of $107 \mathrm{GPU}$ with a $\mathrm{CO}_{2} / \mathrm{CH}_{4}$ selectivity of 3 was obtained under optimized conditions. Due to the low $\mathrm{CNC}$ content in the membranes, it seems the effect of $\mathrm{pH}$ is more important than the $\mathrm{CNC}$. Increasing feed pressure from 5 to 15 bar leads to a dramatic decrease in both $\mathrm{CO}_{2}$ permeance and $\mathrm{CO}_{2} / \mathrm{CH}_{4}$ selectivity.

Torstensen et al. synthesized several different types of nanocellulose and used them for $\mathrm{CO}_{2}$ capture from flue gas [82]. Three different in-house CNF's are compared to commercially CNC and the main focus of the publication was investigating which properties of nanocellulose are important for gas separation membranes. Some of the different nanocellulose properties (different charges, size and functional groups) of CNFs obtained by different pre-treatment steps (TEMPO-mediated oxidation, phosphorylation) are discussed in this paper. The nanocellulose was mixed with PVA and then cast onto a flat sheet polysulfone ultrafiltration membrane. It is a screening study where the nanocellulose content in the hybrid membranes was maintained at $4 \mathrm{wt} \%$ as this concentration would not significantly change the suspension viscosity. The results from mixed gas separation testing show that a high nanocellulose charge and uniform nanoscopic size are favorable nanocellulose properties. A suggested transport mechanism for $\mathrm{CO}_{2}$ in the membrane is suggested where $\mathrm{CO}_{2}$ is transported along the water dense nanocellulose/PVA interfaces.

Very recently, Dai et al. employed CNC and CNF as nanofillers into PVA matrix. The hybrid membrane was fabricated onto a PPO (polyphenylene oxide) hollow fiber substrate [62]. Up to $80 \mathrm{wt} \%$ of nanocellulose was used in the hybrid membranes. By incorporating a large amount of nanocellulose into the PVA matrix, significant improvement can be obtained: increasing CNC content from 0 to $80 \mathrm{wt} \%$ resulted in a dramatic increase in $\mathrm{CO}_{2}$ permeance, from $\sim 400 \mathrm{GPU}$ to $\sim 700 \mathrm{GPU}$. The $\mathrm{CO}_{2} / \mathrm{N}_{2}$ selectivity is almost unchanged. On the other hand, adding CNF into PVA matrix only leads to moderate enhancement in $\mathrm{CO}_{2}$ permeance and the increased selective layer thickness counteracts the improvement raised from the nanocellulose. In addition, the long term stability test was carried out in a period of one year, the membrane maintained good stability in the whole tested range.

\subsection{Nanocellulose/Metal Organic Frameworks Hybrid Membranes}

Metal-organic frameworks (MOFs) have been became as a new class of materials in membrane areas due to their high surface area, controllable pore size, and versatilities in group modification [92]. However, it is challenging to fabricate pure MOF membranes without defects and voids. Thus MOF particles are normally mixed into various polymeric matrices to form hybrid membranes with reasonable flexibility needed in membrane processing [93]. Recently, nanocellulose fibers have been also employed as the flexible polymeric phase to fabricate hybrid membranes containing different MOF particles.

Matsumoto et al. developed a ZIF-90/nanocellulose hybrid membrane by in-situ growth of the MOF particles on the nanocellulose fiber surfaces [94]. The nanocellulose fibers were treated via a TEMPO-mediated oxidation process. Thus, the nanofiber surface has a high density of carboxyl groups, which could form metal-carboxylate complexes with the metal ions in the MOF particles. The MOF/nanocellulose hybrid membranes were fabricated onto a paper filter, with a thickness in the range of $20 \sim 50 \mu \mathrm{m}$. Gas permeation properties of the resultant membrane were tested using a $\mathrm{CO}_{2} / \mathrm{CH}_{4}$ mixture (50:50 vol\%) as the feed gas. As shown in Figure 7, the fabricated MOF/nanocellulose hybrid membranes exhibited ultrahigh $\mathrm{CO}_{2}$ permeance, which is around 3000 GPU. If taking into account of the membrane thickness $(\sim 50 \mu \mathrm{m})$, the gas permeance is corresponding to a $\mathrm{CO}_{2}$ permeability of $\sim 15,000$ Barrers, which is only slightly lower than the well-known the most permeable polymeric material in the world-poly(1-trimethylsilyl-1-propyne) (PTMSP) [95]. 



Figure 7. Gas permeance (a) and $\mathrm{CO}_{2} / \mathrm{CH}_{4}$ selectivity (b) of different ZIF-90/nanocellulose hybrid membranes, reproduced with permission from Reference [94].

In terms of the $\mathrm{CO}_{2} / \mathrm{CH}_{4}$ selectivity, the MOF/nanocellulose hybrid membrane also exhibited a high but unusual trend: the selectivity increases with membrane thickness. The selectivity of the same membrane material can be thickness-dependent when the membrane selective layer thickness is lower than $1 \mu \mathrm{m}$ [96]. However, increasing membrane thickness in micrometer range normally does not change the selectivity. In another work [94], a $\mathrm{CO}_{2} / \mathrm{CH}_{4}$ selectivity value of up to 123 was obtained with a membrane thickness of $\sim 50 \mu \mathrm{m}$. The combination of the gas permeability and selectivity make this $\mathrm{MOF} /$ nanocellulose hybrid membrane extraordinarily promising for $\mathrm{CO}_{2}$ separation applications.

Inspired by Reference [94], Zhang et al. also carried out research work on developing $\mathrm{MOF} /$ nanocellulose hybrid membranes [97]. In their work, $\mathrm{UiO}-66-\mathrm{NH}_{2}$ particles were used instead of the ZIF-90 particles, and nanocellulose fibers with - $\mathrm{COOH}$ group on the surface was employed. The MOF/nanocellulose hybrid membranes were fabricated by vacuum filtration of the MOF and nanocellulose dispersion through a MCE filter with micrometer-sized pores $(0.22 \mu \mathrm{m})$. The resultant membrane shows a thickness of ca. $24 \mu \mathrm{m}$, and the thickness can be controlled by changing the volume of the dispersions. Gas permeation results reveal that, under optimized conditions, adding UIO-66- $\mathrm{NH}_{2}$ particles into the nanocellulose matrix greatly improved both $\mathrm{CO}_{2}$ permeability and $\mathrm{CO}_{2} / \mathrm{CH}_{4}$ selectivity. A $\mathrm{CO}_{2}$ permeability of 139 Barrer and a $\mathrm{CO}_{2} / \mathrm{N}_{2}$ selectivity ratio of 46 was obtained, which is almost 20 times of the neat nanocellulose membranes. However, even though the materials used in Zhang's report and Matsumoto's report, the gas permeability data obtained from Reference [97] is 2 orders of magnitude lower than the value reported in Reference [94].

\subsection{Comparison of Gas Separation Performances and Transport Mechanisms}

Table 1 listed all the $\mathrm{CO}_{2}$ separation performances of various nanocellulose based hybrid membranes.

Based on Table 1, it can be clearly seen that in most of the reported nanocellulose based membranes, the selectivity of $\mathrm{CO}_{2} / \mathrm{N}_{2}$ and $\mathrm{CO}_{2} / \mathrm{CH}_{4}$ are extraordinarily high at humid state, especially when nanocellulose was mixed with facilitated membrane materials (e.g., PVAm) [59]. However, when mixed with polymers based on solution-diffusion mechanism, the presence of nanocellulose does not resulted in a significant change in selectivity (e.g., PVA [62]). Conversely, adding different nanocellulose into non-facilitated transport polymeric matrix normally resulted in a high $\mathrm{CO}_{2}$ permeability/permeance, while the selectivity of $\mathrm{CO}_{2}$ over other gases are almost unchanged [62,82].

The gas separation performances were also plotted in Robeson upper bound, as shown in Figure 8. For both cases, i.e, $\mathrm{CO}_{2} / \mathrm{N}_{2}$ and $\mathrm{CO}_{2} / \mathrm{CH}_{4}$ separation, extremely high selectivity can be obtained in pure nanocellulose membranes or nanocellulose based facilitated transport membranes $[59,86]$. However, for membranes with high selectivity, the $\mathrm{CO}_{2}$ permeability were almost all always in the low region ( $<200$ Barrer). In addition, the maximum selectivity were normally obtained in the $\mathrm{RH}$ range of $65 \%$ to $80 \%$, further increasing the $\mathrm{RH}$ resulted in a higher $\mathrm{CO}_{2}$ permeability but lower selectivity. Based on the gas transport results, a possible gas transport mechanism in nanocellulose based membranes were proposed as shown in Figure 9. 
Table 1. Comparison of $\mathrm{CO}_{2}$ separation performances of different nanocellulose based hybrid membranes.

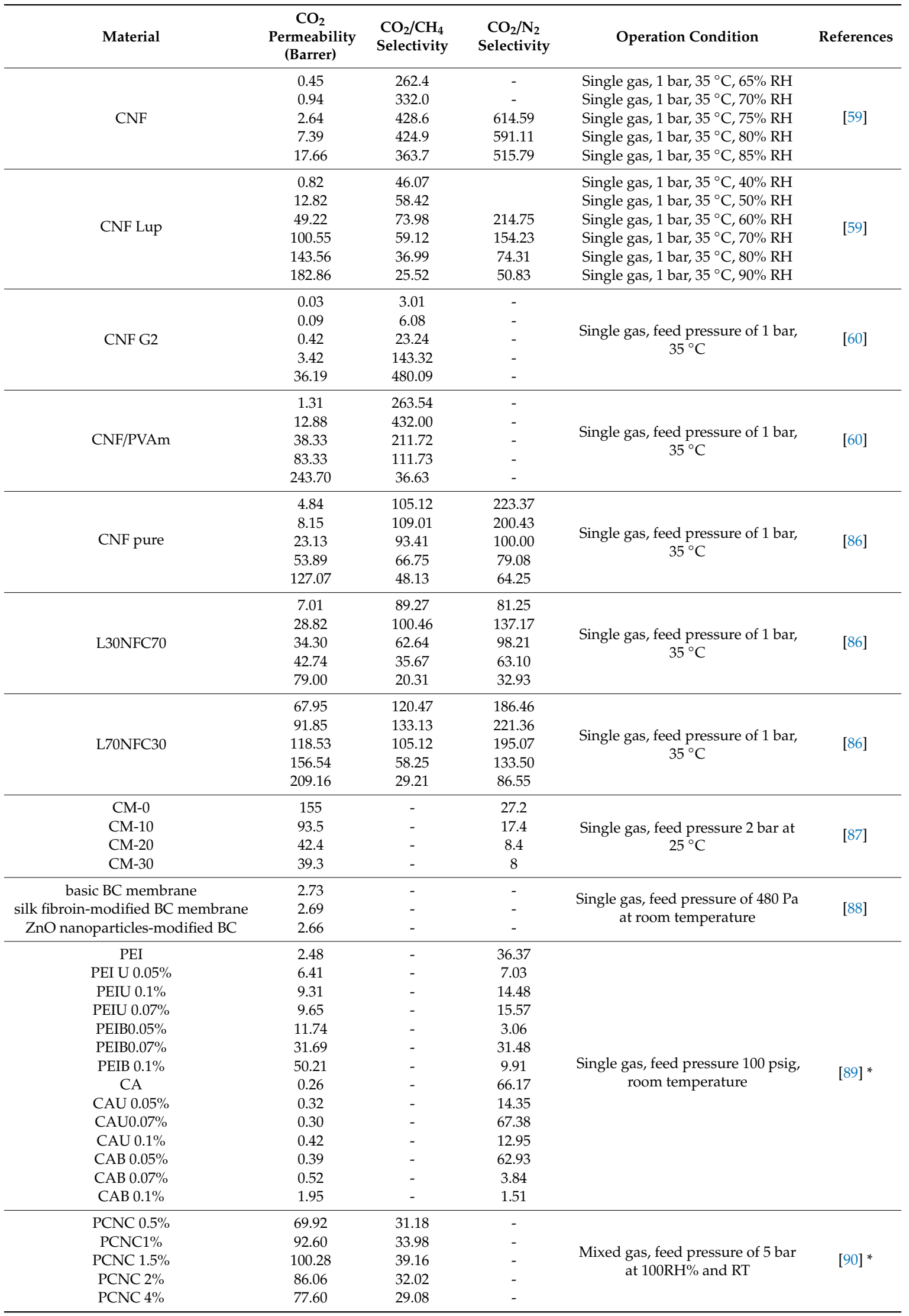


Table 1. Cont.

\begin{tabular}{|c|c|c|c|c|c|}
\hline Material & $\begin{array}{c}\mathrm{CO}_{2} \\
\text { Permeability } \\
\text { (Barrer) }\end{array}$ & $\begin{array}{l}\mathrm{CO}_{2} / \mathrm{CH}_{4} \\
\text { Selectivity }\end{array}$ & $\begin{array}{c}\mathrm{CO}_{2} / \mathrm{N}_{2} \\
\text { Selectivity }\end{array}$ & Operation Condition & References \\
\hline PVA & 105 & - & 36 & \multirow{4}{*}{$\begin{array}{l}\text { Mixed gas, feed pressure of } \\
1.2 \text { bar, } 100 \mathrm{RH} \% \text { and } 23^{\circ} \mathrm{C}\end{array}$} & \multirow{4}{*}[82]{$*$} \\
\hline $\mathrm{PVA} / \mathrm{H}-\mathrm{CNF}$ & 90.7 & - & 42 & & \\
\hline PVA/P-CNF & 100 & - & 42 & & \\
\hline $\mathrm{PVA} / \mathrm{CNC}$ & 128 & - & 39 & & \\
\hline $\mathrm{CNF} / \mathrm{UiO}-66-\mathrm{NH} 2$ & 139 & - & 46 & Single gases, $25^{\circ} \mathrm{C}$ & [97] \\
\hline PVA & 407.16 & - & 33.74 & \multirow{4}{*}{$\begin{array}{l}\text { Mixed gas, feed pressure of } 2 \text { bar } \\
\text { at } 100 \mathrm{RH} \% \text { and RT }\end{array}$} & \multirow{4}{*}[62]{$^{*}$} \\
\hline PVA 20CNC & 480.99 & - & 39.94 & & \\
\hline PVA 40CNC & 549.78 & - & 36.16 & & \\
\hline PVA 60CNC & 616.20 & - & 42.84 & & \\
\hline
\end{tabular}

${ }^{*}$ Gas permeance (GPU) was reported instead of gas permeability (Barrer).

(A)
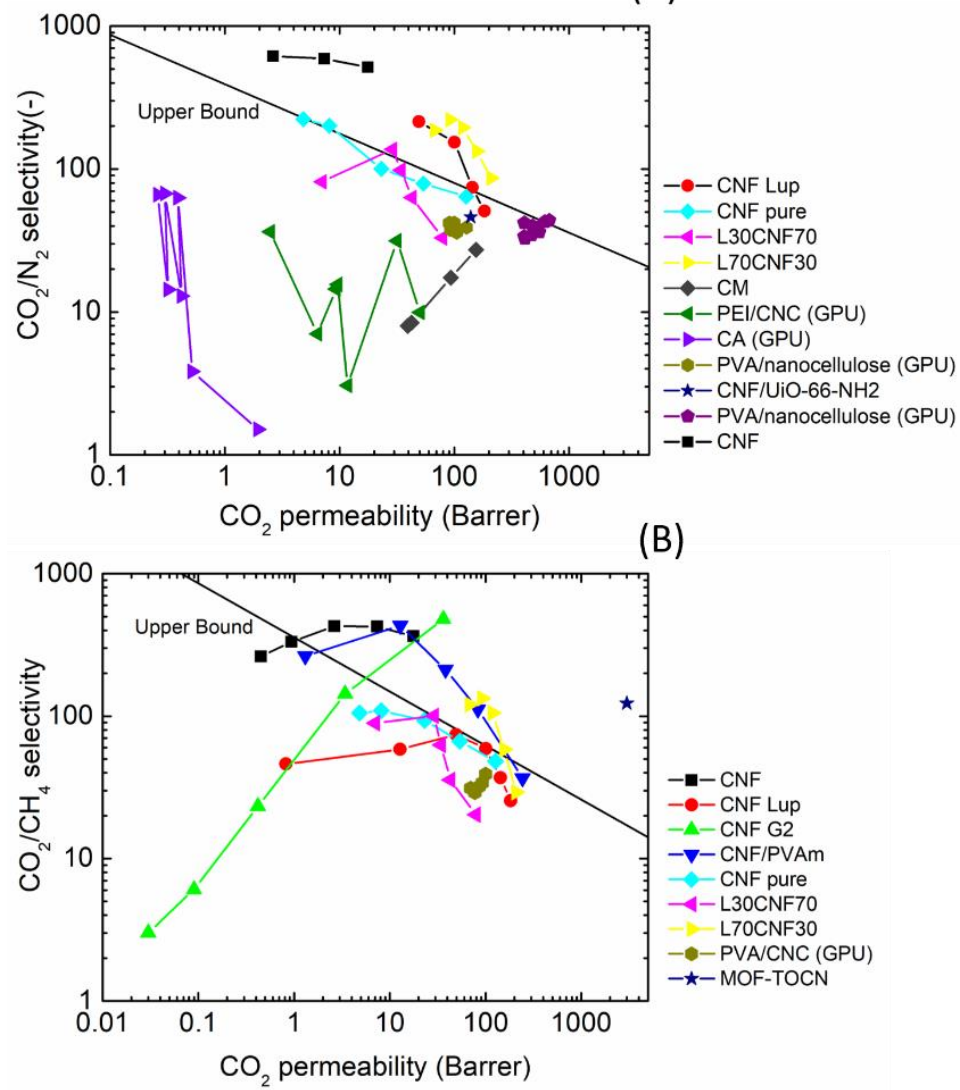

Figure 8. $\mathrm{CO}_{2} / \mathrm{N}_{2}(\mathrm{~A})$ and $\mathrm{CO}_{2} / \mathrm{CH}_{4}$ (B) separation performance plotted in Robeson Upper bound [98].

As discussed before, due to the low gas permeability at dry state or low RH condition, nanocellulose has been proposed as food packaging material. In the case of $\mathrm{CO}_{2}$ separation application, nanocellulose based membrane normally show rather low gas permeability for both $\mathrm{CO}_{2}$ and other gases (e.g., $\mathrm{N}_{2}$ ) at dry state. The densely packed nanocellulose fibers work as gas barrier, which stopped most of the gas molecules from the feed side. When the RH was increased to a medium level (e.g., $60 \sim 80 \% R H$ ), the $\mathrm{CO}_{2}$ gas permeability could be greatly improved, while the gas permeability of other gases (e.g., $\mathrm{N}_{2}$ and $\mathrm{CH}_{4}$ ) were still maintained at a rather low level, thus resulting in extraordinarily high $\mathrm{CO}_{2}$ selectivity over other gases. In this phase, the polymer phase swells with the presence of water vapor, thus 
the distance between the nanocellulose slightly increased. Due to the size difference $\left(\mathrm{CO}_{2} \sim 0.34 \mathrm{~nm}\right.$, $\mathrm{N}_{2} \sim 0.36 \mathrm{~nm}$ and $\mathrm{CH}_{4} \sim 0.38 \mathrm{~nm}$ ), the nanocellulose worked as molecular sieve, the $\mathrm{CO}_{2}$ molecules could diffuse through the space between the nanocellulose fibers whereas $\mathrm{N}_{2}$ and $\mathrm{CH}_{4}$ could not, thus resulted in high $\mathrm{CO}_{2}$ selectivity. Further increase the $\mathrm{RH}$ value resulted in a higher swell degree of the polymeric matrix and consequently larger space between nanocellulose fibers. Therefore, these spaces are big enough for all the gases to pass through, causing the nanocellulose based membrane lose their high selectivity. At high RH conditions, the selectivity of the nanocellulose based membrane are normally dominated by the host polymeric matrix $[62,86]$.
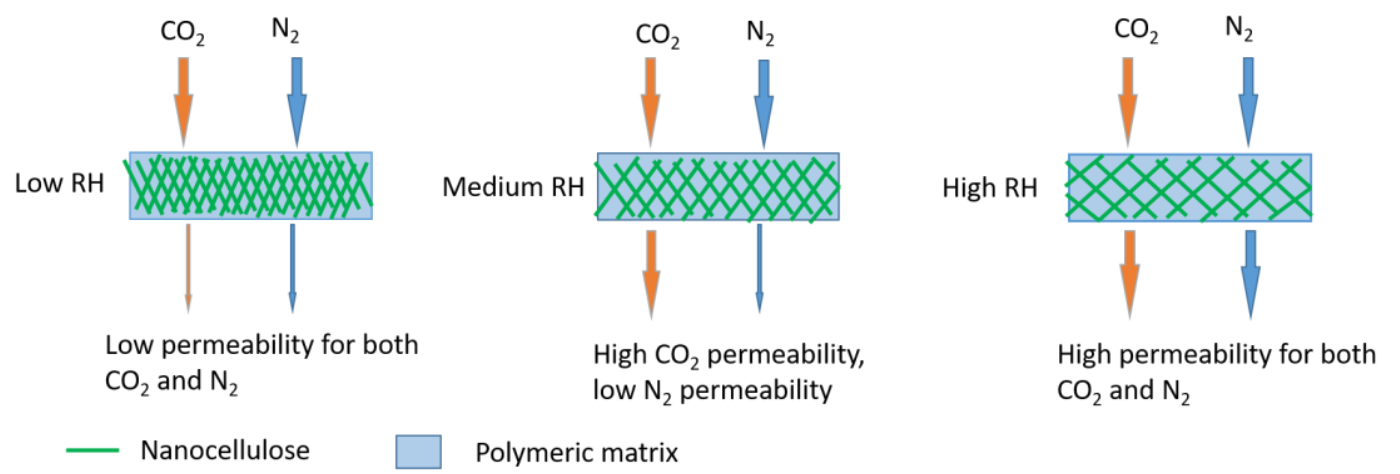

Figure 9. Gas transport in nanocellulose based membranes.

\section{Conclusion and Perspectives}

Nanocellulose holds many different unique properties, such as high mechanical strength and stiffness, high surface reactivity (with numerous hydroxyl groups), specific organization, and nano-sized dimensions. In addition, nanocellulose is abundant, renewable, nontoxic, and biodegradable. All these properties make it a promising material for a diverse range of applications such as paper and packaging products, adsorbents, additives, electronics, and membrane separation processes. The application of nanocellulose based membranes for waste water treatment has also been intensively studied. However, as described in this review, using nanocellulose hybrid membranes for gas separation is a relatively recent application.

According to aforementioned literatures, using nanocellulose in gas separation membranes are quite promising. The presence of nanocellulose in the hybrid membranes leads to either high selectivity or high permeability. In facilitated transport membranes (e.g., (Polyvinylamine, PVAm)), the presence of nanocellulose results in ultrahigh selectivity of $\mathrm{CO}_{2}$ over other gases (e.g., $\mathrm{CH}_{4}$ or $\mathrm{N}_{2}$ ), while the improvement of gas permeability is not as effective. On the other hand, in nanocellulose hybrid polymeric membrane based on solution-diffusion model (e.g., PVA and PEI), the gas permeation can be greatly improved while the selectivity was maintained unchanged. Hybrid membranes fabricated from nanocellulose and (in)organic particles were also studied. Some of these membranes exhibited ultrahigh $\mathrm{CO}_{2}$ permeance and $\mathrm{CO}_{2} / \mathrm{CH}_{4}$ selectivity simultaneously. However, big variations were obtained from membranes fabricated from similar materials. The gas transport mechanism inside these membranes should be further studied and the results should be more concrete.

We expect that the applications of nanocellulose in gas separation membranes will be a topic of intense study in the coming years. However, to make nanocellulose base membrane more competitive to other conventional polymeric membrane materials, some perspectives for future research are proposed:

(1) Fabrication of defect-free TFC membranes with feasible gas permeance is critical. Up to now, many of the reports are using self-standing membranes with a thickness of 50 100 $\mu \mathrm{m}$. However, for practical considerations, to reach a sufficient gas flux through membranes and thus making the separation process economically feasible, membranes containing a defect-free selective layer with athickness ranging from 0.1 to $1.0 \mu \mathrm{m}$ are usually required; 
(2) Work should be done on understanding the gas transport mechanism in nanocellulose based hybrid membranes, thus providing theoretical support for developing optimal membrane materials with both high $\mathrm{CO}_{2}$ permeability and high selectivity;

(3) Gas permeation of the nanocellulose based membranes is moisture sensitive. For most of the nanocellulose hybrid membranes, the highest selectivity was not obtained at the highest relative humidity, thus work should be done to either control the relative humidity in the feed gas, or optimize the nanocellulose hybrid membrane material structure to have the best separation performance at the highest RH.

(4) Functionalization of the nanocellulose may further improve the gas separation performances of the membranes, such as by grafting $\mathrm{CO}_{2}$-philic compounds onto the nanocellulose fiber surface.

(5) The cost of the nanocellulose addition in the hybrid membranes should be evaluated for the possible industrial applications, by considering the balance between the gain from the improved properties and the increased expenses for the nanocellulose addition.

Author Contributions: Conceptualization, L.D. and Z.D.; writing—original draft preparation, Z.D. and V.O.; writing-review and editing, Z.D., V.O., J.D., R.M.L.H. and L.D.

Funding: This research was funded by the European Union's Horizon 2020 Research and Innovation program under Grant Agreement No. 727734. This work would also acknowledge Nano2021 program (NanoMBE, NO. 239172) from the Norwegian Research Council.

Conflicts of Interest: The authors declare no conflict of interest.

\section{References}

1. Moon, R.J.; Martini, A.; Nairn, J.; Simonsen, J.; Youngblood, J. Cellulose nanomaterials review: Structure, properties and nanocomposites. Chem. Soc. Rev. 2011, 40, 3941-3994. [CrossRef] [PubMed]

2. Plackett, D.; Letchford, K.; Jackson, J.; Burt, H. A review of nanocellulose as a novel vehicle for drug delivery. Nordic Pulp Pap. Res. J. 2014, 29, 105-118. [CrossRef]

3. Bodin, A.; Concaro, S.; Brittberg, M.; Gatenholm, P. Bacterial cellulose as a potential meniscus implant. J. Tissue Eng. Regen. Med. 2007, 1, 406-408. [CrossRef]

4. Stark, N.M. Opportunities for cellulose nanomaterials in packaging films: A review and future trends. J. Renew. Mater. 2016, 4, 313-326. [CrossRef]

5. Hubbe, M.A.; Rojas, O.J.; Lucia, L.A.; Sain, M. Cellulosic nanocomposites: A review. BioResources 2008, 3, 929-980.

6. Brodin, F.W.; Gregersen, Ø.W.; Syverud, K. Cellulose nanofibrils: Challenges and possibilities as a paper additive or coating material-A review. Nordic Pulp Pap. Res. J. 2014, 29, 156-166. [CrossRef]

7. Hubbe, M.A.; Tayeb, P.; Joyce, M.; Tyagi, P.; Kehoe, M.; Dimic-Misic, K.; Pal, L. Rheology of nanocellulose-rich aqueous suspensions: A review. BioResources 2017, 12, 9556-9661.

8. Giese, M.; Spengler, M. Cellulose nanocrystals in nanoarchitectonics-towards photonic functional materials. Mol. Syst. Des. Eng. 2019, 4, 29-48. [CrossRef]

9. Lindman, B.; Karlström, G.; Stigsson, L. On the mechanism of dissolution of cellulose. J. Mol. Liq. 2010, 156, 76-81. [CrossRef]

10. Medronho, B.; Romano, A.; Miguel, M.G.; Stigsson, L.; Lindman, B. Rationalizing cellulose (in)solubility: Reviewing basic physicochemical aspects and role of hydrophobic interactions. Cellulose 2012, 19, 581-587. [CrossRef]

11. Glasser, W.G.; Atalla, R.H.; Blackwell, J.; Brown, R.M., Jr.; Burchard, W.; French, A.D.; Klemm, D.O.; Nishiyama, Y. About the structure of cellulose: Debating the Lindman hypothesis. Cellulose 2012, 19, 589-598. [CrossRef]

12. French, A.D. Glucose, not cellobiose, is the repeating unit of cellulose and why that is important. Cellulose 2017, 24, 4605-4609. [CrossRef]

13. Fengel, D.; Wegener, G. Wood: Chemistry, Ultrastructure, Reactions; Walter de Gruyter: Berlin, Germany, 1983.

14. Ottesen, V. Cellulose Nanofibrils as Paper Additive and Coating Material: Properties, Distribution and Interaction Effects; Norwegian University of Science and Technology Trondheim: Trondheim, Norway, 2018. 
15. Klemm, D.; Kramer, F.; Moritz, S.; Lindström, T.; Ankerfors, M.; Gray, D.; Dorris, A. Nanocelluloses: A new family of nature-based materials. Angew. Chem. Int. Ed. 2011, 50, 5438-5466. [CrossRef]

16. Dufresne, A. Nanocellulose: From Nature to High Performance Tailored Materials; Walter de Gruyter GmbH \& Co. KG: Berlin, Germany, 2017.

17. Nechyporchuk, O.; Belgacem, M.N.; Bras, J. Production of cellulose nanofibrils: A review of recent advances. Ind. Crops Prod. 2016, 93, 2-25. [CrossRef]

18. Klemm, D.; Cranston, E.D.; Fischer, D.; Gama, M.; Kedzior, S.A.; Kralisch, D.; Kramer, F.; Kondo, T.; Lindström, T.; Nietzsche, S.; et al. Nanocellulose as a natural source for groundbreaking applications in materials science: Today's state. Mater. Today 2018, 21, 720-748. [CrossRef]

19. Turbak, A.F.; Snyder, F.W.; Sandberg, K.R. Microfibrillated cellulose, a new cellulose product: Properties, uses, and commercial potential. In Journal of Applied Polymer Science: Applied Polymer Symposia; ITT Rayonier Inc.: Shelton, WA, USA, 1983.

20. Czaja, W.K.; Young, D.J.; Kawecki, M.; Brown, R.M. The future prospects of microbial cellulose in biomedical applications. Biomacromolecules 2007, 8, 1-12. [CrossRef]

21. Eriksen, Ø.; Syverud, K.; Gregersen, Ø. The use of microfibrillated cellulose produced from kraft pulp as strength enhancer in TMP paper. Nordic Pulp Pap. Res. J. 2008, 23, 299. [CrossRef]

22. Saito, T.; Kimura, S.; Nishiyama, Y.; Isogai, A. Cellulose Nanofibers Prepared by TEMPO-Mediated Oxidation of Native Cellulose. Biomacromolecules 2007, 8, 2485-2491. [CrossRef]

23. Saito, T.; Isogai, A. Introduction of aldehyde groups on surfaces of native cellulose fibers by TEMPO-mediated oxidation. Colloids Surf. A Physicochem. Eng. Asp. 2006, 289, 219-225. [CrossRef]

24. Ottesen, V.; Kumar, V.; Toivakka, M.; Carrasco, G.C.; Syverud, K.; Gregersen, Ø.W. Viability and properties of roll-to-roll coating of cellulose nanofibrils on recycled paperboard. Nordic Pulp Pap. Res. J. 2017, 32, 179-188. [CrossRef]

25. Hirota, M.; Tamura, N.; Saito, T.; Isogai, A. Water dispersion of cellulose II nanocrystals prepared by TEMPO-mediated oxidation of mercerized cellulose at $\mathrm{pH}$ 4.8. Cellulose 2010, 17, 279-288. [CrossRef]

26. Dong, X.M.; Revol, J.-F.; Gray, D.G. Effect of microcrystallite preparation conditions on the formation of colloid crystals of cellulose. Cellulose 1998, 5, 19-32. [CrossRef]

27. Saïd Azizi Samir, M.A.; Alloin, F.; Paillet, M.; Dufresne, A. Tangling Effect in Fibrillated Cellulose Reinforced Nanocomposites. Macromolecules 2004, 37, 4313-4316. [CrossRef]

28. Brown, A.J. XLIII.-On an acetic ferment which forms cellulose. J. Chem. Soc. Trans. 1886, 49, 432-439. [CrossRef]

29. Jonas, R.; Farah, L.F. Production and application of microbial cellulose. Polym. Degradat. Stab. 1998, 59, 101-106. [CrossRef]

30. Brown, R.M., Jr.; Willison, J.H.; Richardson, C.L. Cellulose biosynthesis in Acetobacter xylinum: Visualization of the site of synthesis and direct measurement of the in vivo process. Proc. Natl. Acad. Sci. USA 1976, 73, 4565-4569. [CrossRef]

31. Zugenmaier, P. Crystalline Cellulose and Derivatives: Characterization and Structures; Springer: Berlin/Heidelberg, Germazny, 2008.

32. Klemm, D.; Heublein, B.; Fink, H.P.; Bohn, A. Cellulose: Fascinating biopolymer and sustainable raw material. Angew. Chem. Int. Ed. 2005, 44, 3358-3393. [CrossRef]

33. Ankerfors, M.; Ström, G.; Öhgren, C.J.I.A.S. Nanocellulose as an additive in foodstuff; Inneventia AB: Stockholm, Sweden, 2013.

34. Gómez, H.C.; Serpa, A.; Velásquez-Cock, J.; Gañán, P.; Castro, C.; Vélez, L.; Zuluaga, R. Vegetable nanocellulose in food science: A review. Food Hydrocoll. 2016, 57, 178-186. [CrossRef]

35. Li, F.; Mascheroni, E.; Piergiovanni, L. The Potential of NanoCellulose in the Packaging Field: A Review. Packag. Technol. Sci. 2015, 28, 475-508. [CrossRef]

36. Azeredo, H.M.C.; Rosa, M.F.; Mattoso, L.H.C. Nanocellulose in bio-based food packaging applications. Ind. Crops Prod. 2017, 97, 664-671. [CrossRef]

37. Khan, A.; Huq, T.; Khan, R.A.; Riedl, B.; Lacroix, M. Nanocellulose-Based Composites and Bioactive Agents for Food Packaging. Crit. Rev. Food Sci. Nutr. 2014, 54, 163-174. [CrossRef] [PubMed]

38. Khalil, H.A.; Davoudpour, Y.; Saurabh, C.K.; Hossain, M.S.; Adnan, A.; Dungani, R.; Paridah, M.; Sarker, M.Z.I.; Fazita, M.N.; Syakir, M. A review on nanocellulosic fibres as new material for sustainable packaging: Process and applications. Renew. Sustain. Energy Rev. 2016, 64, 823-836. [CrossRef] 
39. Ferrer, A.; Pal, L.; Hubbe, M. Nanocellulose in packaging: Advances in barrier layer technologies. Ind. Crops Prod. 2017, 95, 574-582. [CrossRef]

40. Mahfoudhi, N.; Boufi, S. Nanocellulose as a novel nanostructured adsorbent for environmental remediation: A review. Cellulose 2017, 24, 1171-1197. [CrossRef]

41. Puglia, D.; Fortunati, E.; Kenny, J.M. Multifunctional Polymeric Nanocomposites Based on Cellulosic Reinforcements; William Andrew: Norwich, NY, USA, 2016.

42. Dufresne, A. Cellulose nanomaterial reinforced polymer nanocomposites. Curr. Opin. Colloid Interface Sci. 2017, 29, 1-8. [CrossRef]

43. Kargarzadeh, H.; Mariano, M.; Huang, J.; Lin, N.; Ahmad, I.; Dufresne, A.; Thomas, S. Recent developments on nanocellulose reinforced polymer nanocomposites: A review. Polymer 2017, 132, 368-393. [CrossRef]

44. Du, X.; Zhang, Z.; Liu, W.; Deng, Y. Nanocellulose-based conductive materials and their emerging applications in energy devices-A review. Nano Energy 2017, 35, 299-320. [CrossRef]

45. Turbak, A.F.; Snyder, F.W.; Sandberg, K.R. Microfibrillated Cellulose. Google Patents US4374702A, 22 February 1983.

46. Markstedt, K.; Mantas, A.; Tournier, I.; Martínez Ávila, H.C.; Hägg, D.; Gatenholm, P. 3D bioprinting human chondrocytes with nanocellulose-Alginate bioink for cartilage tissue engineering applications. Biomacromolecules 2015, 16, 1489-1496. [CrossRef]

47. Hoeng, F.; Denneulin, A.; Bras, J. Use of nanocellulose in printed electronics: A review. Nanoscale 2016, 8, 13131-13154. [CrossRef]

48. Golmohammadi, H.; Morales-Narvaez, E.; Naghdi, T.; Merkoci, A. Nanocellulose in sensing and biosensing. Chem. Mater. 2017, 29, 5426-5446. [CrossRef]

49. Liu, C.; Du, H.; Dong, L.; Wang, X.; Zhang, Y.; Yu, G.; Li, B.; Mu, X.; Peng, H.; Liu, H. Properties of Nanocelluloses and Their Application as Rheology Modifier in Paper Coating. Ind. Eng. Chem. Res. 2017, 56, 8264-8273. [CrossRef]

50. Shi, Z.; Phillips, G.O.; Yang, G. Nanocellulose electroconductive composites. Nanoscale 2013, 5, $3194-3201$. [CrossRef]

51. Jorfi, M.; Foster, E.J. Recent advances in nanocellulose for biomedical applications. J. Appl. Polym. Sci. 2015, 132. [CrossRef]

52. Karim, Z.; Claudpierre, S.; Grahn, M.; Oksman, K.; Mathew, A.P. Nanocellulose based functional membranes for water cleaning: Tailoring of mechanical properties, porosity and metal ion capture. J. Membr. Sci. 2016, 514, 418-428. [CrossRef]

53. Malakhov, A.O.; Anokhina, T.S.; Petrova, D.A.; Vinokurov, V.A.; Volkov, A.V. Nanocellulose as a Component of Ultrafiltration Membranes. Pet. Chem. 2018, 58, 923-933. [CrossRef]

54. Dai, Z.; Ansaloni, L.; Deng, L. Recent advances in multi-layer composite polymeric membranes for $\mathrm{CO}_{2}$ separation: A review. Green Energy Environ. 2016, 1, 102-128. [CrossRef]

55. Baker, R.W. Membrane Technology and Applications; Wiley Online Library: Hoboken, NJ, USA, 2012.

56. Cheng, Q.; Ye, D.; Chang, C.; Zhang, L. Facile fabrication of superhydrophilic membranes consisted of fibrous tunicate cellulose nanocrystals for highly efficient oil/water separation. J. Membr. Sci. 2017, 525, 1-8. [CrossRef]

57. Mautner, A.; Lee, K.-Y.; Tammelin, T.; Mathew, A.P.; Nedoma, A.J.; Li, K.; Bismarck, A. Cellulose nanopapers as tight aqueous ultra-filtration membranes. React. Funct. Polym. 2015, 86, 209-214. [CrossRef]

58. Metreveli, G.; Wågberg, L.; Emmoth, E.; Belák, S.; Strømme, M.; Mihranyan, A. A Size-Exclusion Nanocellulose Filter Paper for Virus Removal. Adv. Healthc. Mater. 2014, 3, 1546-1550. [CrossRef]

59. Ansaloni, L.; Salas-Gay, J.; Ligi, S.; Baschetti, M.G. Nanocellulose-based membranes for $\mathrm{CO}_{2}$ capture. J. Membr. Sci. 2017, 522, 216-225. [CrossRef]

60. Venturi, D.; Ansaloni, L.; Baschetti, M.G. Nanocellulose based facilitated transport membranes for $\mathrm{CO}_{2}$ separation. Chem. Eng. Trans. 2016, 47, 349-354.

61. Wang, P.-X.; Hamad, W.Y.; MacLachlan, M.J. Structure and transformation of tactoids in cellulose nanocrystal suspensions. Nat. Commun. 2016, 7, 11515. [CrossRef]

62. Dai, Z.; Deng, J.; Yu, Q.; Helberg, R.M.L.; Janakiram, S.; Ansaloni, L.; Deng, L. Fabrication and Evaluation of Bio-Based Nanocomposite TFC Hollow Fiber Membranes for Enhanced $\mathrm{CO}_{2}$ Capture. ACS Appl. Mater. Interfaces 2019. [CrossRef] [PubMed] 
63. Schiffman, J.D.; Schauer, C.L. A Review: Electrospinning of Biopolymer Nanofibers and their Applications. Polym. Rev. 2008, 48, 317-352. [CrossRef]

64. Wang, R.; Guan, S.; Sato, A.; Wang, X.; Wang, Z.; Yang, R.; Hsiao, B.S.; Chu, B. Nanofibrous microfiltration membranes capable of removing bacteria, viruses and heavy metal ions. J. Membr. Sci. 2013, 446, 376-382. [CrossRef]

65. Ma, H.; Burger, C.; Hsiao, B.S.; Chu, B. Nanofibrous Microfiltration Membrane Based on Cellulose Nanowhiskers. Biomacromolecules 2012, 13, 180-186. [CrossRef]

66. Baker, M. The Quest for Pure Water: The History of Water Purification from the Earliest Records to the Twentieth Century; American Water Works Association: Washington, DC, USA, 1949.

67. Voisin, H.; Bergström, L.; Liu, P.; Mathew, A. Nanocellulose-based materials for water purification. Nanomaterials 2017, 7, 57. [CrossRef] [PubMed]

68. Mansouri, J.; Harrisson, S.; Chen, V. Strategies for controlling biofouling in membrane filtration systems: Challenges and opportunities. J. Mater. Chem. 2010, 20, 4567-4586. [CrossRef]

69. Karim, Z.; Mathew, A.P.; Grahn, M.; Mouzon, J.; Oksman, K. Nanoporous membranes with cellulose nanocrystals as functional entity in chitosan: Removal of dyes from water. Carbohydr. Polym. 2014, 112, 668-676. [CrossRef]

70. Hassan, M.; Abou-Zeid, R.; Hassan, E.; Berglund, L.; Aitomäki, Y.; Oksman, K. Membranes based on cellulose nanofibers and activated carbon for removal of Escherichia coli bacteria from water. Carbohydr. Polym. 2017, 9, 335. [CrossRef]

71. Li, Y.; Zhu, L.; Grishkewich, N.; Tam, K.C.; Yuan, J.; Mao, Z.; Sui, X. CO $\mathrm{CO}_{2}$-Responsive Cellulose Nanofibers Aerogels for Switchable Oil-Water Separation. ACS Appl. Mater. Interfaces 2019, 11, 9367-9373. [CrossRef] [PubMed]

72. Zhang, Z.; Sèbe, G.; Rentsch, D.; Zimmermann, T.; Tingaut, P. Ultralightweight and Flexible Silylated Nanocellulose Sponges for the Selective Removal of Oil from Water. Chem. Mater. 2014, 26, 2659-2668. [CrossRef]

73. Jiang, G.-P.; Zhang, J.; Qiao, J.-L.; Jiang, Y.-M.; Zarrin, H.; Chen, Z.; Hong, F. Bacterial nanocellulose/Nafion composite membranes for low temperature polymer electrolyte fuel cells. J. Power Sources 2015, 273, 697-706. [CrossRef]

74. Bayer, T.; Cunning, B.V.; Selyanchyn, R.; Nishihara, M.; Fujikawa, S.; Sasaki, K.; Lyth, S.M. High temperature proton conduction in nanocellulose membranes: Paper fuel cells. Chem. Mater. 2016, 28, 4805-4814. [CrossRef]

75. Gadim, T.D.O.; Vilela, C.; Loureiro, F.J.A.; Silvestre, A.J.D.; Freire, C.S.R.; Figueiredo, F.M.L. Nafion®and nanocellulose: A partnership for greener polymer electrolyte membranes. Ind. Crops Prod. 2016, 93, 212-218. [CrossRef]

76. Vilela, C.; Sousa, N.; Pinto, R.J.B.; Silvestre, A.J.D.; Figueiredo, F.M.L.; Freire, C.S.R. Exploiting poly(ionic liquids) and nanocellulose for the development of bio-based anion-exchange membranes. Biomass Bioenergy 2017, 100, 116-125. [CrossRef]

77. Miettunen, K.; Vapaavuori, J.; Tiihonen, A.; Poskela, A.; Lahtinen, P.; Halme, J.; Lund, P. Nanocellulose aerogel membranes for optimal electrolyte filling in dye solar cells. Nano Energy 2014, 8, 95-102. [CrossRef]

78. Leitch, M.E.; Li, C.; Ikkala, O.; Mauter, M.S.; Lowry, G.V. Bacterial Nanocellulose Aerogel Membranes: Novel High-Porosity Materials for Membrane Distillation. Environ. Sci. Technol. Lett. 2016, 3, 85-91. [CrossRef]

79. Mautner, A.; Lee, K.Y.; Lahtinen, P.; Hakalahti, M.; Tammelin, T.; Li, K.; Bismarck, A. Nanopapers for organic solvent nanofiltration. Chem. Commun. 2014, 50, 5778-5781. [CrossRef] [PubMed]

80. Ferraz, N.; Leschinskaya, A.; Toomadj, F.; Fellström, B.; Strømme, M.; Mihranyan, A. Membrane characterization and solute diffusion in porous composite nanocellulose membranes for hemodialysis. Cellulose 2013, 20, 2959-2970. [CrossRef]

81. Baker, R.W.; Low, B.T. Gas separation membrane materials: A perspective. Macromolecules 2014, 47, 6999-7013. [CrossRef]

82. Torstensen, J.Ø.; Helberg, R.M.L.; Deng, L.; Gregersen, Ø.W.; Syverud, K. PVA/nanocellulose nanocomposite membranes for $\mathrm{CO}_{2}$ separation from flue gas. Int. J. Greenh. Gas Control 2019, 81, 93-102. [CrossRef]

83. Wu, C.-N.; Saito, T.; Fujisawa, S.; Fukuzumi, H.; Isogai, A. Ultrastrong and High Gas-Barrier Nanocellulose/Clay-Layered Composites. Biomacromolecules 2012, 13, 1927-1932. [CrossRef] [PubMed] 
84. Minelli, M.; Baschetti, M.G.; Doghieri, F.; Ankerfors, M.; Lindström, T.; Siró, I.; Plackett, D. Investigation of mass transport properties of microfibrillated cellulose (MFC) films. J. Membr. Sci. 2010, 358, 67-75. [CrossRef]

85. Wang, J.; Gardner, D.J.; Stark, N.M.; Bousfield, D.W.; Tajvidi, M.; Cai, Z. Moisture and Oxygen Barrier Properties of Cellulose Nanomaterial-Based Films. ACS Sustain. Chem. Eng. 2018, 6, 49-70. [CrossRef]

86. Venturi, D.; Grupkovic, D.; Sisti, L.; Baschetti, M.G. Effect of humidity and nanocellulose content on Polyvinylamine-nanocellulose hybrid membranes for $\mathrm{CO}_{2}$ capture. J. Membr. Sci. 2018, 548, 263-274. [CrossRef]

87. Zhang, X.-F.; Hou, T.; Chen, J.; Feng, Y.; Li, B.; Gu, X.; He, M.; Yao, J. Facilitated Transport of $\mathrm{CO}_{2}$ Through the Transparent and Flexible Cellulose Membrane Promoted by Fixed-Site Carrier. ACS Appl. Mater. Interfaces 2018, 10, 24930-24936. [CrossRef]

88. Hosakun, Y.; Halász, K.; Horváth, M.; Csóka, L.; Djoković, V. ATR-FTIR study of the interaction of $\mathrm{CO}_{2}$ with bacterial cellulose-based membranes. Chem. Eng. J. 2017, 324, 83-92. [CrossRef]

89. Uribe, H.A. Effects of Bark Derived Nanocellulose on Gas Separation Membranes; University of Toronto: Toronto, ON, USA, 2018.

90. Jahan, Z.; Niazi, M.B.K.; Hägg, M.-B.; Gregersen, Ø.W. Decoupling the effect of membrane thickness and $\mathrm{CNC}$ concentration in PVA based nanocomposite membranes for $\mathrm{CO}_{2} / \mathrm{CH}_{4}$ separation. Sep. Purif. Technol. 2018, 204, 220-225. [CrossRef]

91. Jahan, Z.; Niazi, M.B.K.; Hägg, M.-B.; Gregersen, Ø.W. Cellulose nanocrystal/PVA nanocomposite membranes for $\mathrm{CO}_{2} / \mathrm{CH}_{4}$ separation at high pressure. J. Membr. Sci. 2018, 554, 275-281. [CrossRef]

92. Caro, J. Are MOF membranes better in gas separation than those made of zeolites? Curr. Opin. Chem. Eng. 2011, 1, 77-83. [CrossRef]

93. Rezakazemi, M.; Amooghin, A.E.; Montazer-Rahmati, M.M.; Ismail, A.F.; Matsuura, T. State-of-the-art membrane based $\mathrm{CO}_{2}$ separation using mixed matrix membranes (MMMs): An overview on current status and future directions. Prog. Polym. Sci. 2014, 39, 817-861. [CrossRef]

94. Matsumoto, M.; Kitaoka, T. Ultraselective Gas Separation by Nanoporous Metal-Organic Frameworks Embedded in Gas-Barrier Nanocellulose Films. Adv. Mater. 2016, 28, 1765-1769. [CrossRef] [PubMed]

95. Dai, Z.; Løining, V.; Deng, J.; Ansaloni, L.; Deng, L. Poly(1-trimethylsilyl-1-propyne)-Based Hybrid Membranes: Effects of Various Nanofillers and Feed Gas Humidity on $\mathrm{CO}_{2}$ Permeation. Membranes 2018, 8, 76. [CrossRef]

96. Rowe, B.W.; Freeman, B.D.; Paul, D.R. Physical aging of ultrathin glassy polymer films tracked by gas permeability. Polymer 2009, 50, 5565-5575. [CrossRef]

97. Zhang, X.-F.; Feng, Y.; Wang, Z.; Jia, M.; Yao, J. Fabrication of cellulose nanofibrils/UiO-66-NH 2 composite membrane for $\mathrm{CO}_{2} / \mathrm{N}_{2}$ separation. J. Membr. Sci. 2018, 568, 10-16. [CrossRef]

98. Robeson, L.M. The upper bound revisited. J. Membr. Sci. 2008, 320, 390-400. [CrossRef] 